\title{
IBM KELOMPOK USAHA GRATIA NATA DE COCO DALAM MEMBUAT LAPORAN KEUANGAN MENGGUNAKAN MICROSOFT EXCEL
}

\author{
Frida Magda Sumual, SE, M.Acc \\ Fakultas Ekonomi Universitas Negeri Manado \\ E-mail : fridasumual@unima.ac.id
}

\begin{abstract}
ABSTRAK
UD. Gratia Coco di desa Paslaten Kecamatan Tomohon Tengah merupakan produsen nata de coco di Kota Tomohon. UD Gratia Coco selama ini telah mensuplai beberapa Supermarket dan produsen makanan olahan berbahan baku nata yang tersebar di Kota Tomohon dan Kota Manado. Namun demikian, perusahaan ini masih dikelola secara tradisional. Usaha Home Industri Nata de coco UD Gratia Coco didirikan atas dasar perlunya aktifitas ekonomi dalam menunjang kesejahteraan keluarga. Pada awal perkembangannya, perihal bahan baku, teknologi produksi serta pemasaran tidak dijumpai kendala yang berarti. Namun demikian, permintaan nata de coco semakin hari semakin bertambah, sehingga diperlukan manajemen bisnis yang baik salah satunya yaitu pengelolaan keuangan yang baik dengan pembukuan/penyusunan laporan keuangan. Laporan keuangan merupakan informasi paling krusial yang mengendalikan seluruh aktivitas perusahaan. Sayangnya, banyak pebisnis yang belum menyadari pentingnya laporan keuangan bagi perusahaan.Pada kenyataanya praktek kegiatan UKM selalu berjalan tanpa mengandalkan informasi keuangan yang disusun secara tertib dan teratur. Kegiatan ini dapat dikatakan cukup berhasil selain dapat dilihat dari antusias para peserta dapat juga dilihat dengan terjadinya peningkatan kemampuan para peserta dalam menyusun laporan keuangan.
\end{abstract}

Kata Kunci : Laporan Keuangan, Microsoft Excel

\section{PENDAHULUAN}

Pengelolaan penerapan TI dalam suatu bisnis tidak terbatas pada ketersediaan tools yang ada,tetapi memerlukan sumber daya manusia (SDM) yang berkompeten dalam penguasaan TI.Namun, sayangnya belum semua wirausaha memiliki SDM yang mendukung untuk pengelolaanTI.

Keterbatasan SDM yang dimiliki wirausaha bisa disebabkan karena ketidak mampuan pengelola UKM dalam memanfaatkan penggunaan TI, atau keterbatasan modal yang dimilikisehingga belum mampu untuk merekrut pegawai yang kompeten dalam bidang TI.Sehingga,SDM merupakan faktor yang penting dalam mempersiapakan pengelolaan TI dalam setiap bisnisdan usaha yang dijalankan, serta kemampuan untuk bersaing dan bertahan dalam pasar.Teknologi informasi merupakan segala bentuk teknologi yang diterapkan untuk memproses dan mengirimkan informasi dalam bentuk elektronis. Wirausaha berbasis teknologi informasi adalah pemanfaatan teknologi informasi dalam berbagai kegiatan usaha yang dilakukan dalam kewirausahaan. Penerapan teknologi informasi ini dapat berwujud dalam berbagai bentuk, sebagai contoh penerapan teknologi informasi dalam Penyusunan laporan keuangan. Harapannya, dengan pemanfaatan teknologi ini usaha yang dijalankan dapat memperoleh keuntungan 
yang lebih dibandingkan dengan wirausaha yang tidak berbasis teknologi informasi.

UD. Gratia Coco di desa Paslaten Kecamatan Tomohon Tengah merupakan produsen nata de coco di Kota Tomohon. UD Gratia Coco selama ini telah mensuplai beberapa Supermarket dan produsen makanan olahan berbahan baku nata yang tersebar di Kota Tomohon dan Kota Manado. Namun demikian, perusahaan ini masih dikelola secara tradisional. Usaha Home Industri Nata de coco UD Gratia Coco didirikan atas dasar perlunya aktifitas ekonomi dalam menunjang kesejahteraan keluarga. Dipilihnya jenis usaha ini didasari tersedianya bahan baku berupa limbah air kelapa dipasar-pasar sekitar Tomohon yang kurang dimanfaatkan secara maksimal dan adanya teknologi pengolahan Nata de coco yang di kuasai beberapa tahun yang lalu. Usaha yang dimulai sejak tahun 2001 telah mengalami pasang surut. Pada awal perkembangannya, perihal bahan baku, teknologi produksi serta pemasaran tidak dijumpai kendala yang berarti. Namun demikian, permintaan nata de coco semakin hari semakin bertambah, sehingga diperlukan manajemen bisnis yang baik salah satunya yaitu pengelolaan keuangan yang baik dengan pembukuan/penyusunan laporan keuangan.

\section{SOLUSI DAN TARGET LUARAN}

Sekarang ini banyak pengusaha kecil dan menengah belum bisa menyusun pembukuan/laporan keuangan secara benar cepat dan tepat sehingga mereka mengalami kesulitan dalam pengelolaan keuangannya sehingga keputusan yang diambil tidak berdasarkan fakta yang ada tidak adanya informasi atau kurangnya informasi yang bernilai guna berdampak dalam hal salah pengambilan keputusan atau salah dalam hal penetapan strategi bisnis untuk bersaing. Pembuatan laporan keuangan untuk setiap pelaku usaha UKM secara tepat dan cepat dengan memakai TI diharapkan dapat mengatasi permasalahan ini. Salah satunya adalah dengan pemanfaatan Komputer Aplikasi Excel dalam proses penyusunan laporan keuangan.

Berdasarkan uraian permasalahan yang dihadapi, maka target dalam kegiatan IbM ini adalah pengelola usaha kecil dan menengah UD. Gratia Coco. Dengan adanya informasi keuangan secara cepat dan tepat akan menghasilkan keputusan yang stretegis dan tepat, maka usahaakan berjalan dengan lancar dan mendapatkan keuntungan yang ditargetkan, sehingga hal ini bisamemperkuat dan mengembangkan bisnis.

\section{METODE PELAKSANAAN}

Langkah langkah yang dilakukan untuk melaksanakan serangkaian kegiatan yang diharapkan dapat menyelesaikan permasalahan yang dihadapi mitra adalah sebagai menggunakan metode ceramah, tutorial, praktek mandiri, dan diskusi. Adapun sistematika pelaksanaan kegiatan pengabdian ini adalah sebagai berikut:

$>$ Langkah 1 (Metode Ceramah): 
Peserta diberikan motivasi agar memiliki

kesadaran mengenai pentingnya laporan keuangan dan pengelolaan keuangan dalam usaha selama 2 jam.

$>$ Langkah 2 (Metode Tutorial):

Peserta pelatihan diberikan materi pengembangan wirausaha kecil dan menengah dan penjualan produk wirausaha selama2 jam.

\section{> Langkah 3 (Praktek Mandiri):}

Peserta pelatihan diberikan materi konsep dan tata cara pembuatan laporan keuangan menggunakan Aplikasi Excel dibagi 2 sesi masing-masing 2 jam.

\section{Langkah 3 (Metode Diskusi):}

Peserta pelatihan diberikan kesempatan untuk mendiskusikan permasalahan yang berkaitan dengan Pengembangan usaha dan pengelolaan keuangan serta penyusunan laporan keuangan 2 jam.

\section{KELAYAKAN PERGURUAN TINGGI}

Kinerja LPM Universitas Negeri Manado sudah menunjukkan hasil yang baik. Dalam rangka meningkatkan kualitas tenaga pendidik/dosen, LPM secara rutin menyelenggarakan pelatihan penulisan proposal pengabdian masyarakat, sehingga kemampuan dosen menulis dan daya saing proposal meningkat. Secara garis besar telah dijelaskan berbagai macam jenis usulan serta waktu yang disediakan. Selain kinerja internal, LPM juga aktif melaksanakan kegiatan yang berhubungan dengan pihak di luar Universitas Negeri Manado dalam berbagai bidang. LPM Universitas Negeri
Manado juga memiliki Road Map sehingga semua kebijakan dan kegiatan yang dilakukan dapat lebih terarah menuju sasaran.

\section{HASIL DAN PEMBAHASAN}

Kegiatan IbM ini dapat dikatakan cukup berhasil dilihat dari jumlah peserta yang hadir mengikuti kegiatan bimbingan baik pemilik dan pegawai di UKM Gratia Nata De Coco. Pentingnya laporan keuangan untuk menunjang kegiatan membuat tenaga administrasi yang ada sangat antusias mengikuti kegiatan ini dengan mengajukan pertanyaan mengenai penyusunan laporan keuangan dengan menggunakan Microsoft Excel. Kegiatan ini dapat dikatakan cukup berhasil selain dapat dilihat dari antusias para peserta dapat juga dilihat dengan terjadinya peningkatan kemampuan para peserta dalam menyusun laporan keuangan. Pada awalnya para peserta yang sebagian besar berlatar belakang pendidikan SMA/SMK dan sederajat belum mengetahui pentingnya penyusunan laporan keuangan yang mencerminkan posisi keuangan dari UKM Gratia Nata De Coco sehinggan belum menyusun laporan rugi/laba, neraca, dll. Selain itu, awalnya perserta mengalami permasalahan dengan ketidakmampuan penggunaan komputer s sebagai alat bantu dalam melaksanakan pekerjaan khususnya aplikasi mircosoft excel. 


\section{KESIMPULAN DAN SARAN}

\section{Kesimpulan}

Adapun kesimpulan kegiatan ini yaitu (1) Kegiatan pengabdian pada masyarakat ini pada dasarnya telah dilaksanakan dengan baik antara pelaksana, peserta dan pimpinan dalam memberikan bimbingan penyusunan laporan keuangan menggunakan komputer dengan program mircosoft excel untuk menunjang kegiatan di UKM Gratia, (2) Kegiatan bimbingan ini adalah merupakan langkah awal sehingga masih diperlukan adanya kegiatan lanjutan berupa pelatihan yang lebih intensif guna meningkatkan kemampuan para peserta dalam penyusunan laporan keuangan, (3) Pelaksanaan kegiatan bimbingan ini sangatlah dibutuhkan bagi tenaga administrasi yang ada di UKM Gratia, yang pada akhirnya dapat menunjang program pemerintah dalam bidang ekonomi.

\section{Saran}

1. Kegiatan semacam ini perlu dilakukan untuk memberikan bimbingan penyusunan laporan keuangan menggunakan komputer dengan program mircosoft excel untuk menunjang kegiatan di UKM Gratia.

2. Kegiatan semacam ini kiranya terus dilakukan oleh LPM Unima Manado sebagai tugas tridharma perguruan tinggi, dengan tetap melaksanakan pemantauan dan evaluasi atas segala kegiatan di lapangan.

\section{KEPUSTAKAAN}

Benjamin, W.P., (1990). Laporan Keuangan (Ikhtisar Akuntansi) Perusahaan Kecil, Dalam, Dalam Prosiding, Seminar Akuntan Nasional, Surabaya.

Burke, J.F., (1997). Report on Standards Overload, CPA Journal, 66(3), p11.

Holmes, S. (1986). The role of practising accountants, accounting information and small business owner/manager. Australia, 259-284.

Holmes, S., \& Nicholls, D. (1988). An analysis of the use of accounting information by Australian small business. Journal of Small Business Management, 26 (2), 57 - 69.

Holmes, S., \& Nicholls, D. (1989). Modeling the accounting information requirements of small businesses. Accounting and Business Research, 19 (74), 143-150.

Knutson, D.L., \& Wichmann, Jr, H., (1985). The Issue of Differential Accounting Treatment For American Small Businesses, Management Forum, Vol. 11 Sept.

Muntoro, R. K. 1990, Praktek Akuntansi Keuangan, Dalam Prosiding, Seminar Akuntan Nasional, Surabaya.

Nair, R.D, Reittenberg, dan Larry, E., (1983). Privately Held Businesses: Is There a Standards Overload?, Journal of Accountan, New York.

Nayla, Akifa, P. 2014. Komplet Akuntansi Untuk UKM dan Waralaba. Jakarta: Laksana.

Raharjo, M. D., \& Ali, F. (1993). Faktorfaktor keuangan yang mempengaruhi usaha kecil dan menengah di Indonesia, Dalam K. James \& N. Akrasanee, Aspek-aspek finansial usaha kecil dan menengah; Studi kasus Asean, (pp. 16-50). Jakarta: LP3ES. 